\title{
Motivating Activities in Test Preparation Writing Classes: A Case Study in Vietnam
}

\author{
Nguyen Thi Thuy Loan \\ Suranaree University of Technology, Thailand
}

\begin{abstract}
TOEFL iBT and IELTS preparation courses have become increasingly popular in Vietnam over the past few years due to the increasing demand for overseas study. However, little research has been conducted into how to teach these courses effectively and interestingly. This paper describes action research that aims to discover activities that motivate students in TOEFL iBT and IELTS writing classes at a private foreign language center in Vietnam. The paper shares findings from a qualitative study involving the researcher's observations, questionnaires for writing teachers and students, and course evaluations carried out by the center. Class diaries, teacher expertise, and activities organized in a communicative way tended to motivate these students. The findings suggest a new model for effectively teaching English in a culturally-based context of learning that exists in Vietnam (Ellis, 1994; Le Ha, 2004; Lewis \& McCook, 2002) and in other Asian countries with similar cultural values.
\end{abstract}

Recently, Vietnamese learners have had a tendency to earn degrees from foreign countries. This has led to a demand for English courses for learners to prepare for studying abroad, which the public school curriculum cannot meet. To meet learners' objectives, many private English language centers provide academic English courses focusing on test preparation (e.g., TOEFL iBT and IELTS).

To attract more students and encourage teachers to provide interesting lessons for students, classrooms in English as a foreign language (EFL) centers have been equipped with networked computers, speakers, and projectors. Some centers have even prepared e-materials (original academic English textbooks are scanned and audio files are added) for teachers to use to improve effectiveness and encourage teachers to be innovative. Some teachers now employ the communicative language teaching approach $(C L T)$ or design and modify textbook material with software to move away from traditional ways of teaching students with just a textbook.

Despite these improvements, in a survey by the researcher (see Appendix A) of teachers of writing, three-quarters of these teachers reported that the general atmosphere in their writing courses was "quiet" (see Appendix B). (Vietnamese teachers teach writing and reading skills 
while native English-speaking teachers teach listening and speaking at this center.) Issues influencing the situation were identified:

First, students at EFL centers come to evening language classes with different levels of extrinsic motivation. Some take TOEFL iBT or IELTS classes to improve their employment prospects or to prepare for admission to higher education institutions in foreign countries. Some come to class simply because their parents force them to do so. Some students attending TOEFL iBT or IELTS evening writing classes may be motivated, but are exhausted after spending the day working or studying.

Second, written English is not the main focus in most Vietnamese high schools. Writing is used as a convenient mode for testing grammar or vocabulary. This is because of the belief that students should have mastered the language at the sentence level before attempting to write paragraphs.

Finally, students' writing suffers from interference from the Vietnamese language and Vietnamese writing discourse habits. As opposed to British and American discourse patterns, which tend to be linear, Vietnamese discourse patterns tend to be circular. In addition, some students are inclined to think in their own language when writing and translate their ideas word for word from Vietnamese. Both of these tendencies create difficulties in producing formal written English.

With respect to the issues identified above, the aim of this project was to investigate whether or not activities developed by the researcher to motivate students in her TOEFL iBT and IELTS writing classes were effective. Results of this qualitative research may assist test preparation writing teachers at EFL centers to organize their writing classes according to their students' expectations.

\section{Literature Review}

Brown (2000) defines motivation from three different perspectives. In behavioristic terms, motivation is driven by external and individual forces. Previous experiences of reward drive a person to act to achieve further positive reinforcement. In cognitive terms, motivation refers to the need to explore the unknown, to move, and exercise mentally and physically. In a constructivist perspective, motivation is viewed in a social context where each person is motivated differently and acts in ways that are unique within his or her cultural and social milieu. Brown (2000) emphasizes that learning a foreign language requires learners to have some of all three aspects of motivation, which together are typically known as intrinsic and extrinsic motivation.

Dörnyei (2001) suggested various strategies for establishing, generating, and maintaining motivation in a foreign language classroom. To establish motivational conditions in class, he suggested that teachers take students' learning seriously by showing that they care about their progress and have sufficiently high expectations for what they can do. In addition to this, teachers should also regularly use small group tasks or activities that employ features of CLT, aiming to promote the development of group cohesiveness.

Dörnyei (2001) also stated that teachers need to know students' goals, interests, and expectations to motivate the students and organize appropriate class activities. Besides this knowledge, to maintain students' level of motivation, teachers should vary learning tasks to make them enjoyable and challenging enough for students to complete. Furthermore, teachers 
need to provide prompt and positive feedback about progress and areas on which students should particularly concentrate to engage their intrinsic motivation (Dörnyei, 2001).

Similarly, Nett, Goetz, and Hall (2011) placed strong emphasis on teachers' role in maintaining students' attention and taking into account their different needs, interests, abilities, and beliefs about learning English. In addition, research by Urdan and Schoenfelder (2006) on the effects of classrooms on student motivation indicates that relationships between teachers and students positively influence students' intrinsic motivation. They explain that unmotivated students can become engaged in activities if they believe that their teachers care for and support them by tailoring these activities to their needs and interests. With regard to the impact of classroom environments on language learners' intrinsic motivation, Yunus, Osman, and Ishak (2011) determined that by creating a supportive learning environment, teachers can stimulate learners' intrinsic motivation.

Ellis (1994) argues that besides teachers' efforts to motivate their students, teachers of English in Vietnam need to take into consideration students' culture-based learning styles to be successful. In relation to the interactive relationship between language and culture, the idea that suitable teaching methods involve teachers' ability to adapt materials to make them culturally appropriate (Ellis, 1994) seems to fit into the Vietnamese EFL teaching and learning context. Ellis (1996) also highlights the need to integrate local cultural norms into CLT employed in the classroom to be effective. Similarly, Le Ha (2004) confirms that to be successful teachers in Vietnam, teachers should locate themselves across two identity roles. As a teacher of English, the teacher should organize and get students involved in many language activities to learn English naturally, and as a "Vietnamese" teacher, the teacher needs to take into account socially-expected roles such as "behavior educator," "moral guide," or "students' confidant": someone who understands their needs and expectations.

In addition to culture-based learning styles, successful teachers in Vietnam need to know how learning autonomy is developed to facilitate their students' engagement in class. From his discussion on Vietnamese learner autonomy in learning English as a foreign language, Dang (2010, p. 4) states that in Vietnam, learning autonomy is "a socially-bound capacity," not an ability to work alone. He also emphasizes that Vietnamese students can become motivated and willing to take part in a learning process if enough encouragement is provided. He explains this by arguing that young learners in Vietnam consider knowledge from their teachers as "the only one correct source" (p. 6). This is because young Vietnamese learners are generally regarded as not ready to deal with many choices. Therefore, asking them to look for many knowledge resources on their own is likely to discourage them from class participation because they are familiar with "learning from their teachers" (p. 6).

Research to date has tended to focus on the integration of the learning cultures of Vietnamese students into CLT in the EFL teaching context in Vietnam as a way of raising students' interest in learning English. However, this does not place any emphasis on teaching a specific language skill. In addition, Pham (2005), a lecturer and teacher educator in Vietnam, has shared his ideas about the need for teachers to "reexamine some of their traditional beliefs and assumptions about language teaching and learning" (para. 32) when integrating Western features of CLT into the Vietnamese educational, social, and cultural contexts. He also suggests that studies should be conducted on how Vietnamese teachers incorporate the key concepts of a Western version of CLT into their own classes. With this in mind, this paper seeks to investigate whether or not a certain number of communicative activities based on the 
above theoretical elements would be well-received and effective in TOEFL iBT and IELTS writing classes at an EFL center in the south of Vietnam.

\section{Methodology}

An action research approach was chosen within an interpretative paradigm to understand and interpret the current situation, the feelings of both teachers of writing classes and their students about the effectiveness of the activities. In accordance with the cycles of action research described by Coghlan and Brannick (2010), the research contained four stages: constructing, planning action, taking action, and evaluating action.

The constructing stage began when the researcher observed that some teachers were not pleased when assigned to teach writing courses. In the planning action stage, the researcher developed six questions (see Appendix A) to ask the ten writing teachers at the center about their writing classes and how they reacted to their own classroom situation to verify the researcher's observations and to learn more about how the teachers felt (see Appendix B).

The taking action stage involved the development of a range of activities with the aim of creating a positive atmosphere in TOEFL iBT and IELTS writing classes (see Appendices C and D). The criteria for organizing writing activities were:

- provide learners with achievable tasks (Harmer, 1991),

- design and organize writing tasks that help students master the language and skills needed to complete the tasks before asking them to write a coherent and well organized answer or essay, and

- $\quad$ select tasks of interest to students if possible (Dörnyei, 2001).

These activities were developed and taught by the researcher and were then evaluated by 92 students in seven pre-intermediate to advanced level TOEFL iBT and IELTS evening writing classes over a period of approximately eight months. Ten open-ended questions were then used to collect students' opinions on the effectiveness of the activities (see Appendix E).

The evaluating action phase involved the researcher performing a thorough interpretation of the data collected from the first three stages. In this final stage, the researcher also asked for the center's permission to examine feedback on the researcher's performance in these courses to help confirm the effectiveness of the activities.

\section{Results and Discussion}

\section{Teacher Evaluation}

The results of the survey administered by the center with these students gave support to the researcher's belief in the effectiveness of the activities used in the classroom. Approximately two-thirds of students agreed that their teacher's performance was "good" (62\%) and almost a third said their teacher was "excellent." Only five out of ninety-two students reported that their teacher was either "satisfactory" (5\%) or "average" (1\%). None reported being unhappy with their teacher. 


\section{Table 4}

Results of Class Surveys on the Teacher's Performance by the Language Center

\begin{tabular}{|c|c|c|c|c|c|}
\hline & Excellent & Good & Satisfactory & Average & Unsatisfactory \\
\hline $\begin{array}{c}\text { Number of } \\
\text { students }\end{array}$ & 30 & 57 & 4 & 1 & 0 \\
\hline Percentage (\%) & 32 & 62 & 5 & 1 & 0 \\
\hline
\end{tabular}

Note. $N=92$

\section{Student Questionnaire}

A questionnaire (see Appendix E) designed to evaluate the effectiveness of the activities was administered at the end of the course. The findings of the questionnaire are ordered below according to the level of importance given to the activities by the students.

Regular Feedback (Question 6). The results showed that $92 \%$ of students were happy to regularly receive teacher feedback on their writing. This demonstrates that the use of a teaching diary has very motivating outcomes. This activity also demonstrates the importance of the socially-expected role of teachers in Vietnam, who should act as the "students' confidant" (Le Ha, 2004) in class. In fact, teachers in these courses are expected to know their students' strengths and weaknesses and to instruct them appropriately on how to improve. By doing this on a regular basis, the teachers' role in class is similar to that of parents at home in Vietnam, who are always beside their children with advice and instructions. Socially-expected roles aside, regular feedback also reflects the teachers' care for the students' writing, thus meeting one of Dörnyei's suggestions for creating the basic motivational classroom (Dörnyei, 2001). Additionally, reporting on students' mistakes based on the teacher's notes is supported by Urdan and Schoenfelder's findings (2006) about teachers' roles in motivating their students in the classroom. Finally, showing students that their teachers accept them as they are and take their learning very seriously by checking and returning their writing quickly and with positive and encouraging feedback is highly appreciated. This strategy is proposed by Dörnyei (2001) and works well with this group of students in Vietnam.

\section{Table 5}

\section{Results of Class Survey on Activities}

\begin{tabular}{|c|c|c|c|c|c|c|c|c|}
\hline Activities & $\begin{array}{c}\text { Pair work, } \\
\text { group work \& } \\
\text { class discussion }\end{array}$ & Visuals & $\begin{array}{c}\text { Language } \\
\text { for writing }\end{array}$ & $\begin{array}{c}\text { Good } \\
\text { samples }\end{array}$ & $\begin{array}{c}\text { Bad } \\
\text { samples }\end{array}$ & $\begin{array}{c}\text { Teaching } \\
\text { diary }\end{array}$ & Websites & Others \\
\hline $\begin{array}{c}\text { Number of } \\
\text { students }\end{array}$ & 76 & 76 & 74 & 72 & 69 & 85 & 71 & 80 \\
\hline $\begin{array}{c}\text { Percentage } \\
(\%)\end{array}$ & 82.6 & 82.6 & 80.4 & 78 & 75 & 92 & 77.2 & 87 \\
\hline
\end{tabular}

Note. $N=92$

Teacher Expertise (Question 10). As can be seen in Table 5, 87\% of students were motivated by such activities as in which the teacher demonstrated expertise when completing "strange" tasks, such as explaining unusual charts that students brought to the class. This technique was designed to create trust in the teacher's expertise as this shows that the teacher is able to do not 
only prepared exercises in the course book, but also completely new ones. Students may also feel proud of themselves because of the new, useful, and interesting tasks they discover. This conforms to the constructivist view of motivation (Brown, 2000) in Vietnamese contexts, because in Vietnamese culture, students value their teachers as masters (Dang, 2010) and they mostly respond in a positive and respectful way to those whose teaching is interesting. This cultural value in English language teaching is also accepted by almost all of the writing teachers in the survey (see Appendix B), where nine out of ten agreed that students' confidence in their teachers' ability was important in creating a positive atmosphere in class.

Interactive Activities (Questions 3 \& 4). Pair work, group work, and class discussion were reported to be useful in building students' confidence in their writing (82.6\%). Additionally, these interactive activities exhibit the feature of integrating culturally-based learning styles into consideration in organizing tasks (Ellis, 1994, 1996). In these activities, students' needs for sufficient correct information to organize answers to given tasks were taken into account. In particular, students need to know exactly what they will write in each answer. By directing them toward the skills and language they need, teachers guarantee their students that they will be successful in performing the tasks (Dörnyei, 2001). Students' extrinsic motivation aside, these interactive activities also reflect Dang's discussion on how encouragement is provided to get students' involvement and gradually develop their learning autonomy (Dang, 2010). In addition, this way of organizing activities in these writing classes partly responds to the suggestions by Pham (2005) on how Vietnamese teachers incorporate the key concepts of a Western version of CLT into their own classes in the Vietnamese educational, social, and cultural contexts.

Useful Language for Writing (Question 5). In the same perspective, providing students with language for writing, e.g., useful expressions, sentence structures, and vocabulary related to each writing task, was reported to be helpful $(80.4 \%)$. This can be done by first inviting students to share with their friends the vocabulary related to the given topic they already know and then the teacher adding more to the students' vocabulary list. Helping students with language for writing before they write on their own also reflects students' high expectations of their teachers. Teachers are expected to be better than their students and they are supposed to offer the help (the language) the students need for each writing task. By doing this, teachers act out the expected role of teacher of English (Le Ha, 2004) and build their learners' trust in their teaching ability, which positively affects students' intrinsic motivation (Harmer, 1991).

Despite the difference in learner autonomy in Vietnam (Dang, 2010), the researcher in this study also helped her students find their own learning path by providing them with choices and negotiations in respect to learning something new and on their own with the available resources (e.g., the Internet).

\section{Limitations and Suggestions}

The researcher acknowledges that involving more teachers and carrying out interviews with students would have provided more data about the current teaching situation and presented more information about students' expectations. However, the aim of the study was not to generalize, but to gain some insights into what Vietnamese students at an EFL center expected their writing teachers to do in their TOEFL iBT and IELTS test preparation courses.

Additionally, this study aimed to satisfy the researcher's curiosity about what makes the practice of teaching these courses effective and interesting. Although this research identified some ways to motivate students in TOEFL iBT and IELTS writing classes at a specific center, more studies of this kind at other EFL centers in Vietnam as well as in countries with similar 
educational conditions should be conducted to provide a more complete picture of how teachers conduct their writing classes in the various cultural contexts of EFL learning and teaching.

\section{Conclusion}

The present study sought to suggest what writing teachers of TOEFL iBT and IELTS writing classes might do to get their students involved in their classes. Based on the researcher's observations, questionnaires for both writing teachers and students, and a course evaluation administered, the results of this study support previous findings suggesting that a culturallybased style of learning (Ellis, 1994) needs to be integrated into class activities.

Besides teachers' expertise and interactive activities based on CLT, Vietnamese students seem to expect their teachers to care about their studies and to show that they are always available with academic support. The cultural expectations of students identified in this action research project also provide insight for foreign teachers who wish to be successful in Vietnam.

Although each EFL center is unique, integrating cultural norms into the communicative approach seems essential for effective teaching in Vietnam and in other Asian countries with similar cultural values.

\section{Author Note}

Nguyen Thi Thuy Loan, School of Foreign Languages, Institute of Social Technology, Suranaree University of Technology, Thailand.

The author would like to gratefully acknowledge Professor Andrew Lian for his insightful advice, encouragement, and generous support for the completion of this project. Also, I would like to thank my colleagues and students for their cooperation and enthusiastic assistance in my project. Finally, my sincere thanks also go to the Board of Directors of SEAMEO RETRAC, Vietnam and especially the ELT Department for their permission and support to conduct this research.

Correspondence concerning this article should be addressed to Nguyen Thi Thuy Loan, School of Foreign Languages, Institute of Social Technology, Suranaree University of Technology, Muang, Nakhon Ratchasima, 30000 Thailand. E-mail: thuyloancailay@yahoo.com 


\section{References}

Brown, H. D. (2000). Principles of language learning and teaching (4th ed.). White Plains, NY: Pearson Education.

Coghlan, D., \& Brannick, T. (2010). Doing action research in your own organization (3rd ed.). London, England: Sage.

Dang, T. T. (2010). Learner autonomy in EFL studies in Vietnam: A discussion from sociocultural perspective. English Language Teaching, 3(2), 3-9.

Dörnyei, Z. (2001). Motivational strategies in the language classroom. Cambridge, England: Cambridge University Press.

Ellis, G. (1994). The appropriateness of the communicative approach in Vietnam: An interview study in intercultural communication (Master's thesis). Bundoora, Victoria, Australia: La Trobe University. Available from ERIC database. (ED378839)

Ellis, G. (1996). How culturally appropriate is the communicative approach? ELT Journal, 50(3), 213-218. http://dx.doi.org/10.1093/elt/50.3.213

Harmer, J. (1991). The practice of English language teaching (New ed.). UK: Longman.

Le Ha, P. (2004). University classrooms in Vietnam: Contesting the stereotypes. ELT Journal, 58(1), 50-57. http://dx.doi.org/10.1093/elt/58.1.50

Lewis, M., \& McCook, F. (2002). Cultures of teaching: Voices from Vietnam. ELT Journal, 56(2), 146-153. http://dx.doi.org/10.1093/elt/56.2.146

Nett, U. E., Goetz, T., \& Hall, N. C. (2011). Coping with boredom in school: An experience sampling perspective. Contemporary Educational Psychology, 36(1), 49-59. http://dx.doi.org/10.1016/j.cedpsych.2010.10.003

Pham, H. H. (2005). "Imported" communicative language teaching: Implications for local teachers. English Teaching Forum, 43(4), 2-9. Available at http://eca.state.gov/forum/vols/vol43/no4/p2.htm

Ur, P. (1996). A course in language teaching. Cambridge, England: Cambridge University Press.

Urdan, T., \& Schoenfelder, E. (2006). Classroom effects on student motivation: Goal structures, social relationships, and competence beliefs. Journal of School Psychology, 44(5), 331 349. http://dx.doi.org/10.1016/j.jsp.2006.04.003

Yunus, M. M., Osman, W. S. W., \& Ishak, N. M. (2011). Teacher-student relationship factor affecting motivation and academic achievement in ESL classroom. Procedia - Social and Behavioral Sciences, 15(0), 2637-2641. http://dx.doi.org/10.1016/j.sbspro.2011.04.161 


\section{Appendix A \\ Questionnaire on Teachers' Writing Practice}

Dear colleagues,

Would you please help me answer 6 questions in the survey below by writing your answer directly under each question?

It is an informal survey about your writing practice. The results of this study will be treated confidentially and will be made available to you if requested.

I shall be very grateful if you can finish them at your earliest convenience. Please return the completed questionnaires by January 10, 2010.

Thank you so much for your assistance.

Please provide some of your biographical information

Gender: M ... F.... Age: ..... Degree held: B.A .... M.A.... PhD....

1. Are you pleased when you are assigned to a TOEFL iBT / IELTS writing class?

2. Do you follow the course book without any deviation or modify it with your own materials? Why?

3. If you supplement students with your own materials, do you have any criteria for selecting them? If yes, what are they?

4. Do you think that students' confidence in their teachers' ability to teach the skill is important in creating a positive atmosphere in the class?

5. What is the general atmosphere in your writing class? (boring, exciting, quiet...)

6. What do you do if your students are not happy in your writing class?

Thank you 


\section{Appendix B}

Teachers' Ideas on Their Writing Practice

\begin{tabular}{|c|c|c|c|c|c|c|c|c|c|}
\hline Teacher & Age & Gender & Degree & $\begin{array}{c}\text { Feelings } \\
\text { about } \\
\text { teaching } \\
\text { TOEFL / } \\
\text { IELTS } \\
\text { writing } \\
\end{array}$ & $\begin{array}{l}\text { Modify } \\
\text { course } \\
\text { book }\end{array}$ & $\begin{array}{l}\text { Criteria for } \\
\text { material } \\
\text { selection }\end{array}$ & $\begin{array}{c}\text { Belief on } \\
\text { students' trust } \\
\text { in teachers' } \\
\text { ability }\end{array}$ & $\begin{array}{c}\text { General } \\
\text { class } \\
\text { atmosphere }\end{array}$ & $\begin{array}{c}\text { Reactions to quiet } \\
\text { classes }\end{array}$ \\
\hline 1 & 52 & $\mathrm{~F}$ & BA & Pleased & Yes & $\begin{array}{c}\text { Something } \\
\text { different, } \\
\text { additional }\end{array}$ & $\begin{array}{l}\text { Yes, very } \\
\text { important }\end{array}$ & Quiet & $\begin{array}{l}\text { Give them } \\
\text { something } \\
\text { challenging }\end{array}$ \\
\hline 2 & 60 & $M$ & BA & Pleased & Yes & $\begin{array}{c}\text { Clear, } \\
\text { systematic and } \\
\text { appropriate to } \\
\text { students' level }\end{array}$ & Yes & Exciting & $\begin{array}{c}\text { Find out why and } \\
\text { adjust the class } \\
\text { activity to their } \\
\text { suggestions }\end{array}$ \\
\hline 3 & 34 & $\mathrm{~F}$ & MA & Pleased & Yes & Yes & Yes & $\begin{array}{c}\text { Sometimes } \\
\text { quiet, } \\
\text { sometimes } \\
\text { exciting }\end{array}$ & $\begin{array}{c}\text { Change the } \\
\text { teaching method } \\
\text { and look for the } \\
\text { cause }\end{array}$ \\
\hline 4 & 40 & $\mathrm{~F}$ & MA & Pleased & Yes & \begin{tabular}{|c|} 
Structure \\
practice; \\
Vocabulary \\
building; \\
Skill practice \\
for TOEFL iBT \\
or IELTS tasks; \\
Interesting \\
topics \\
\end{tabular} & $\begin{array}{c}\text { Yes, one of } \\
\text { the few } \\
\text { reasons to get } \\
\text { them join } \\
\text { classwork } \\
\text { and } \\
\text { homework }\end{array}$ & Exciting & $\begin{array}{l}\text { Vary activities } \\
\text { Provide games } \\
\text { Create class } \\
\text { writing blog Give } \\
\text { them scores }\end{array}$ \\
\hline 5 & 50 & M & MA & So so & Yes & A lot & Yes & Quiet & $\begin{array}{l}\text { Make them work } \\
\text { (write or discuss) }\end{array}$ \\
\hline 6 & 40 & $\mathrm{~F}$ & MA & So so & Yes & Yes & Yes & $\begin{array}{c}\text { Not very } \\
\text { exciting } \\
\text { and not } \\
\text { very quiet }\end{array}$ & $\begin{array}{c}\text { Use pair work and } \\
\text { group work }\end{array}$ \\
\hline 7 & 45 & M & MA & No & Yes & $\begin{array}{c}\text { Appropriate to } \\
\text { course book } \\
\text { objectives }\end{array}$ & Yes & Ok & $\begin{array}{l}\text { Look for } \\
\text { something } \\
\text { interesting to } \\
\text { entertain them }\end{array}$ \\
\hline 8 & 57 & M & MA & No & Yes & $\begin{array}{c}\text { Provide useful } \\
\text { language, } \\
\text { samples from } \\
\text { low to high } \\
\text { levels } \\
\end{array}$ & Yes & Motivating & $\begin{array}{l}\text { Think about how } \\
\text { to motivate them }\end{array}$ \\
\hline 9 & 56 & M & BA & No & Yes & $\begin{array}{c}\text { Students' level } \\
\& \text { age }\end{array}$ & Partly & $\begin{array}{c}\text { Exciting } \\
\text { most of the } \\
\text { time, but } \\
\text { sometimes } \\
\text { boring }\end{array}$ & $\begin{array}{l}\text { Change the } \\
\text { teaching method, } \\
\text { talk to them to } \\
\text { find out the cause }\end{array}$ \\
\hline 10 & 51 & $F$ & BA & No & Yes & $\begin{array}{l}\text { Something } \\
\text { new }\end{array}$ & Yes & So so & $\begin{array}{l}\text { Keep them busy } \\
\text { Supplement with } \\
\text { interesting } \\
\text { materials }\end{array}$ \\
\hline
\end{tabular}




\section{Appendix C}

A Summary of Activities and Techniques Used by the Researcher

\begin{tabular}{|c|c|}
\hline $\begin{array}{c}\text { Class Activities } \\
\text { and } \\
\text { Techniques }\end{array}$ & Application \\
\hline Pair work & $\begin{array}{l}\text { Integrated writing (TOEFL iBT Task 1): } \\
-\quad \text { exchanging notes made from reading and listening materials with other } \\
\text { - } \quad \text { students } \\
\text { IELTS Writing Task 1: } \\
-\quad \text { analyzing visual data (discussing overall trends \& key data) } \\
-\quad \text { orally describing the charts (instead of individual writing) } \\
-\quad \text { writing the answer (after orally describing the charts with their partner) } \\
\text { Peer correction: } \\
-\quad \text { checking first draft writing } \\
-\quad \text { giving each other feedback on content, language and organization (see } \\
\text { Ur, 1996, p. 171, for its usefulness) }\end{array}$ \\
\hline Group work & $\begin{array}{l}\text { Integrated writing (TOEFL iBT Task 1): } \\
\text { - } \quad \text { note taking on the content of the reading and listening } \\
\text { - } \text { paraphrasing, summarizing, and synthesizing the content of the reading } \\
\text { and listening: these activities give each student exposure to various } \\
\text { paraphrased sentences, and this helps enrich their sentence structures } \\
\text { - } \quad \text { making an outline for the answer, ensuring that students know how the } \\
\text { answer to each task should be organized } \\
\text { IELTS Writing Task 1: } \\
\text { - } \quad \text { interpreting visual data (discussing overall trends and key data) } \\
\text { IELTS and TOEFL iBT Task 2: } \\
\text { - brainstorming ideas before students write the answer (getting more ideas, } \\
\text { - } \quad \text { outlining (helping students logically arrange their ideas) } \\
\text { Peer correction: } \\
\text { offering students a chance to exchange their ideas about mistakes as well } \\
\text { as the good points they picked up from their friends }\end{array}$ \\
\hline $\begin{array}{c}\text { Class } \\
\text { discussion }\end{array}$ & $\begin{array}{l}\text { Integrated writing (Task } 1, \text { TOEFL iBT): } \\
\text { - checking students' work on summarizing, paraphrasing, and synthesizing } \\
\text { the reading and listening materials or providing them with necessary } \\
\text { vocabulary, expressions and structures } \\
\text { - orally constructing the answer (all students taking turns to orally add and } \\
\text { join sentences to construct a complete answer instead of writing it out } \\
\text { quietly and individually) }\end{array}$ \\
\hline
\end{tabular}




\begin{tabular}{|c|c|}
\hline $\begin{array}{l}\text { Class } \\
\text { discussion } \\
\text { (continued) }\end{array}$ & $\begin{array}{l}\text { Brainstorming: } \\
\text { - checking students' ideas from pair or group discussions (sharing the ideas } \\
\text { that each group developed in their discussion before writing a complete } \\
\text { answer on their own) } \\
\text { All tasks (Tasks } 1 \& 2 \text {, TOEFL iBT \& IELTS): } \\
\text { - analyzing samples of good or bad writing pieces written by other students } \\
\text { (student writing pieces which were intentionally chosen by teachers to } \\
\text { enhance students' awareness about what was right or wrong in their } \\
\text { writing) }\end{array}$ \\
\hline Visuals & $\begin{array}{l}\text { Using PowerPoint and Hot Potatoes (to change the class atmosphere; useful } \\
\text { for Task } 1 \text { IELTS \& TOEFL iBT) to teach, show, or practise: } \\
\text { note-taking } \\
\text { paraphrasing and summarizing } \\
\text { using transitional words } \\
\text { reorganizing mixed sample answers } \\
\text { the theory of how to write an academic essay } \\
\text { samples of good introductory or concluding paragraphs } \\
\text { (See some examples of PowerPoint lessons from this website: } \\
\text { http://www.virtual.yosemite.cc.ca.us/lumanr2/English_25/index.htm) }\end{array}$ \\
\hline Teaching diary & $\begin{array}{l}\text { Keeping a notebook with students' names to note each student's strengths, } \\
\text { weaknesses, common mistakes, scores obtained for each writing piece, and } \\
\text { individual reports on the progress of selected students in need of private help } \\
\text { in their writing }\end{array}$ \\
\hline Other & $\begin{array}{l}\text { Moving around the class while students are writing to observe and note } \\
\text { students' interesting ideas or common mistakes on the board or on the } \\
\text { computer screen } \\
\text { Checking and quickly returning writing assignments with positive and } \\
\text { encouraging feedback } \\
\text { Using symbols on a list of correction keys (e.g. "N" for mistakes with noun } \\
\text { usage, "V" for verbs, "sp" for spelling and "vt" for verb tenses) } \\
\text { Encouraging students to ask questions to clarify their mistakes } \\
\text { Encouraging students to bring "strange or new" materials, such as unusual } \\
\text { charts, to class (Task 1, IELTS) } \\
\text { Suggesting some useful writing websites for students to study on their own at } \\
\text { home (Appendix D) } \\
\text { Providing students with some kind of entertainment in writing (video clips of } \\
\text { topics relevant to the integrated writing tasks in the course book) }\end{array}$ \\
\hline
\end{tabular}




\section{Appendix D \\ Some Useful IELTS / TOEFL iBT / Academic Related Sites}

Essay Writing:

http://www.virtual.yosemite.cc.ca.us/lumanr2/English_25/index.htm

IELTS Writing:

http://www.ieltstips.com/ielts_test/about_ielts/online_ielts_resources.html

http://www.ielts-test-practice.com/ielts-resource.html

http://www.examenglish.com/IELTS/IELTS_writing.htm

http://www.aippg.com/ielts/ielts-downloads.htm

http://www.youtube.com/watch?v=z-zHcoGdUg8

TOEFL iBT Writing:

http://i-courses.org/?p=writing_tips

Academic English Wordlists:

http://www.nottingham.ac.uk/ alzsh3/acvocab/

http://www.academicvocabularyexercises.com/

BBC Podcasts:

http://www.bbc.co.uk/podcasts/ 


\section{Appendix E \\ Student Survey on Writing Classes}

To help your teacher improve the effectiveness in teaching writing, please answer the following questions in English or Vietnamese. Your cooperation is highly appreciated.

1. Are you interested in the PowerPoint lessons your teacher used in class? Do these lessons better help you focus on the lessons? Why? Why not?

2. Do you think the lessons created by Hot Potatoes are useful in your writing classes? Why? Why not?

3. Do you think the pair work and group work your writing teacher organizes in your current writing class is effective or not? Why or Why not?

4. Do you think it is necessary for you and your friends to discuss the given topic before you write a complete essay about it? Why? Why not? Are you interested in working with your friends to write the answer in class?

5. Do you think the useful expressions and sentence structures for each kind of writing given by your teacher are helpful to you in your writing the answer or not? Why or why not?

6. Are you interested in being informed about your strengths and weaknesses in your writing by your teachers? Why?

7. Do you think reading good writing samples given by your teacher is useful? How does that help you?

8. Do you think reading and analyzing mistakes in the writing by another student is helpful? How does it help you?

9. Do you find the websites suggested by your teacher useful? How? Why and why not?

10. What do you think of some other activities organized by your writing teacher, such as moving around the class and showing you your mistakes or good ideas for writing, providing you some kinds of entertainment, asking you to bring strange tasks to the class, and the way she provides you feedback on your writing?

Other comments:

Thank you 